\title{
Impact of Corporate Diversification on Real Option as a Component of Marker Value of Firms: Evidence from Nairobi Securities Exchange
}

\author{
David Onguka \\ University of Nairobi, Nairobi, Kenya
}

\begin{abstract}
This study aimed at determining effect of corporate diversification on real option as a component of market value of firms. Hypotheses were formulated and tested for sixty four listed firms at the NSE. The study applied census survey since population under study is countable. The time frame of analysis is five years between 2013 and 2017.Out of the 64 listed companies targeted, 52 were analyzed forming $81 \%$ of the population. A positivistic research philosophy was used since it's based on quantification of phenomena under study. Correlational descriptive research designs and correlation analysis were applied. Formulated hypotheses were tested by application of hierarchical multiple regression analysis. The results show a direct significant association between the variables line with previous studies findings. The findings can be used by the management to value joint ventures independently at point of termination. The study can also benefit scholars by providing analytical tools to make strategic decisions. Policy Makers will use the study to craft relevant corporate regulations on real option investments.
\end{abstract}

Keywords: Corporate diversification, real option, market value of firms, globalization

DOI: $10.7176 /$ RJFA/10-2-02

\subsection{Introduction}

Valuation approach for determining the true value of a company has remained a hotly contested subject by investors and academicians alike. Traditional valuation methods like net present value increasingly give unreliable firm valuation as the gap between market value and economic value continue to widen as the economy metamorphoses into service and information base (Pater, 2002). The motivation for undertaking this study is to find out whether real option approach would be the panacea that financial economics and investors need to fill this gap. Myers (1977) first proposed option pricing theory as an alternative in valuing growth opportunities plus firm's specific options that can be accessed by companies. Subsequently, number of studies has proposed different models to value the various options held by firms key one being real option- that is by the decisions that are yet to be made but for which the firm has adequate resources and capacity to undertake. (Kester, 1984; Smit, 2000; \& Danbolt et al., 2002). Paddock et al. 1988, Quigg 1993 \& Adam and Goyal, 2002)

Real option investment is based on delaying some strategic decisions on investments other than doing it at once in pre-planning stage (Rita et al., 2004). The approach relies of sound management, organizational structure and systems employed by the firm (Kogut \& Kulatilaka, 2001). It provide appropriate heuristic framing of capabilities and competencies. Real options are not an obligation but rights to sell or buy specific products at a fixed price and future date. Such rights develop from patents and trademarks of the firm. The study seeks to determine factors that influence market value of real option and how organization can use its resources efficiently to exploit market opportunities. One of the key factor identified by past studies is corporate diversification incorporating both product and geographical diversification as well as degree of specialization as the sub-variables (P. de Andre's-Alonso et al. 2005). The key focus of this study is establish the role played by corporate diversification in influencing real option component of market value of stock.

\subsection{Corporate Diversification}

Corporate diversification is management strategy used by firms to minimize risks by investing in different portfolios (Paddock et.al., 1988). A number of study findings indicate that locational and portfolio diversification contributes greatly to success of companies (Kester, 1984\& P. de Andre's-Alonso et al. 2005). The process of investing in new lines of business and new areas provides new exposures and experiences thereby generating new knowledge that can be leverage on by the firm for future growth in current and new areas and business lines. The generated unique knowledge gives the firm a competitive advantage and provide future potential options for growth that pushes up its value. It therefore follows that by participating in different lines of business and markets, a firm would be innovative to efficiently compete in the market. The company will also have options of switching resources between different markets where it has presence depending on products and markets situations which gives it a greater flexibility. This means that barring correlation, diversification strategy is more profitable than specializing in one line of business success of the strategy lies on the capacity of management to acquire and manage the availed options. According to Kester (1984) obtaining excessive options may be 
counterproductive as it may lead to inefficiency due to limited finances. According to Sanchez (1995) best strategy for the company is to concentrate its resources in expansion of its business and only diversify to profitable options that will not constrain resources.

With flexible and strategic management, diversification strategy broadens the scope of growth opportunities (Sua' rez, 1994). Market diversification has a significant and a positive influence on the real option market value. The measurement sub variables adopted for corporate diversification are internal diversification, degree of specialization and globalization.

\subsection{Real options; a component market value of stock.}

Amram and Kulatilaka (1999) defined real options as investments which gives a firm right to execute defined investments in future at will. Real option deals with real asset other than financial assets. A number of studies show that real option portfolios take greater percentage in determining firm market value. Real options are decision under consideration, but for whose undertaking the firm is well positioned (Pablo de Andres-Alonso et al., 2005).According to Black and Scholes (1973), real option is derived from financial options contracts in that it gives the firm rights to decide to execute the contract at a definite exercise price and date. (Rita et al. 2004). The right to execute the contract at strike price is limited to expiration period.

Market value of stock refers to the realizable value based on the prevailing selling prices of its shares for a quoted company or the price which a buyer of a private company is willing to offer for its full acquisition (Rita, 2004). According to Peter (2002), the gap between the market value of stocks and actual value based on discounted value of its perpetual cash flows, has been on upward trend for some time as the economy becomes increasingly service and information based. He however noted that this can only occur in the presence of risk and its intelligent application. Option theory therefore allows us to calculate the strategic premium referred to as the real option value which when combined with the value realized from the firm's already invested assets (AIA). This view is indirectly supported by Pablo de Andres-Alonso et al, (2005) who contend that real options valuation is a reflection of management's efficiency to investment in phases and realise profits.

Already invested asset value is defined as a specific investment incurred whose value is obtained as discounted value of stream of cash flows generated over a period similar to traditional direct cash flow model normally used to value the company as a whole. Real option theory postulates that; value of the company is not only derived from a particular allocation of resources as in AIA but from the resources themselves and cash flows realized from alternative allocations in future. Therefore deferred investments have a right since they affect future possible cash flows and the value of such rights is the key aim of real option approach.

Estimating the value of real options by direct means in line with financial options approach from which the real option approach is derived has proved to be a challenge. Part of the reason is that a generalised way to do this has not been adequately defined and no comprehensive theory gives the process employed by investors in assessing the effect of management decision on real option. Pablo de Andres-Alonso et al, (2005) postulated that the nature and composition of real option value is affected by both tangible and intangible asset which has been acquired by the company over its life period and not always sufficiently accounted for in its financials. Similar to financial options, real options value is a component of time to expiration, the strike price and unique characteristics of its underlying assets, which investors do not have access to. These limitations makes determination of real options value by investors - by direct method - an almost impossible task. The only viable alternative for investors is to derive this by indirect method - which has also been adopted by this study. This method bases the value of real options as present value of cash flows expected from already invested assets (AIA). Working of ROV captures the value of these factors which show efficiency of firm to implement option diversification - identification, acquisition, maintainace and selling. According to Sharp, (1991) \& Bowman and Hurry, (1993) efficient flow of information to the management helps firms to acquire most valuable options, avoid duplication of options and take advantage of available options on a timely manner. Such companies also have established a system of allocating decisions rights at various levels of the organization as well as adequate incentives and controls mechanisms to optimize on recognition, acquisition, maintenance and effective exercise or implementation the options to optimize on the stock value of real option.

\subsection{Research Problem}

Previous research findings have made it clear that the value of a firm is not only a factor of capitalized value of firm's cash flows as was initially believed based on traditional valuation techniques. Empirical finding of past studies such as Kester $(1984,1986)$ whose findings indicated that the capitalized value of firm's perpetual cash flows accounts for less than $50 \%$ of the market values of a number of companies. Their findings also show that for companies with high growth potential and high market demand, the estimate hardly covers $20 \%$ of the market value. As argued by Peter (2002), it is not strange to find the market value of service based firms exceeding its book value by $20 \%$. A number of studies therefore have proposed and developed new models which factor in corporate investments decisions. These are investment decision which the management delays 
their implementation but has adequate resource capacity to execute (Paddock et al., 1988). But these studies only focused on specific industry or provided only estimates but not empirical evidence.

The problem is that it is still not clear how investors' expectations regarding these future potential of the company which influence their decision on stock pricing is reflected in the market value of stocks. As economy become more and more information and service based and with increased volatility of regional stock exchanges, valuation techniques such as net present value (NPV) are unable to give concrete value of firms (Sanchez, 1995). It is therefore imperative that factors which have significant influence on stock price are identified and empirical analysis done. However, unlike financial options, a number of factors influencing the real options market price are not directly observable.Pablo de Andres-Alonso et al, (2005)argues that corporate diversification is key factor in stock price determination but focused only on non-financial firms listed in the Spanish Stock Exchange. This study aimed to investigate the notion that investors' expectations regarding value of future decisions options available to a firm is incorporated in the stock prices. This study seeks to establish the effect of corporate diversification on real option as a component of market value of stock for firms listed in the NSE.

\subsection{Literature Review}

Several theories explain the relationship between corporate diversification and real option value including composite value theory of Myers (1997), the market efficiency theory of Fama (1970 and the real option theory of Amram and Kulatilaka of (1999).

Composite value theory states that market value of stock is compost of capitalized net present values and market option value resulting from management flexibility to take decision (Myers, 1977). DCF approach assumes investments reversibility and that the management has to act now or never which is contrary to real option approach. This was pointed out by Dixit et al. (1994) who argued that many investments do not confirm to this criteria and who postulated that the reality of uncertainty and flexibility has a value which will impact projects and therefore influences investment decision taken by the management in addition to value derived from capitalized current cash flow of the firm. According to Trigeorgies (1996), discretionary nature of investment has a value which is recognized by real option approach since the management has a responsibility to determine the direction of investment. Furthermore, Dixit and Pindyck (1994) argued that management constantly reviews investments plans continually as new information is acquired. Raffaele and Maurizo (2010), concluded that the value of investment in new technologies increases with the variance of their expected returns. According to this theory, company assets are composed of already acquired assets and future investment plans.

Salma and Hussein (2018) found that managers and directors proportion of share held, firm growth rate, the size and nature of risk exposure are significantly influenced by firm diversification and performance. They postulated that diversification is an important tool in managing fluctuating product uptake and high volatility in the industry thereby increasing survival chance of a firm by empowering it to adopt to changing environment. They, however, pointed that this needs to be complimented by management capability and well-designed strategies to be successful realized.

According to EMH, stock prices reflect fully the circulating information in the market and past information is of no use to predict future stock prices. There are various forms of efficiencies. These include strong form efficiency, weak form efficiency and medium form efficiency. Under real option valuation, the stock market is assumed to represent medium form efficiency in which historical and public available information is reflected in the stock prices.

Amram and Kulatilaka (1999) defined real option as the right excised at will to execute future contracts based favourable changes in unpredictable events. Rita et al. (2004) postulated that real option strategy has inherent risk due to uncertainty of future events but its more advantageous than making all decisions in preplanning phase. Real option gives alternative profitable investment options based on future events. Real option valuation is derived from financial option valuation (Black and Scholes, 1973). Bowman and Hurry (1993) have since developed and analysed methods of valuing options specifically on real assets. There are different methods to execute real option strategy by management. The management can postpone investment, change the amount of finances invested (growth, scaling and abandonment options), or alter movement of investment (switching options). Lyandres et al. (2015) liked worldwide economic systems to corporate branching out and express the need to put together the recognised connections while taking into account environmental unpredictability so as to provide a vibrant and complete justification of corporate diversification.

\subsection{Operationalization of Corporate Diversification}

It's measured by Herfindahl Index (HERF) as shown by equation below

$\mathrm{HERF}=1-\sum_{i}^{n} p_{\mathrm{i}} . \mathrm{W}_{\mathrm{i}}$

Where $\boldsymbol{n}$ is No. of portfolios, $\boldsymbol{p}_{\boldsymbol{i}}$ is revenues of activity $\boldsymbol{i}$, and $\mathbf{w}_{\mathbf{i}}$ a weighted coefficient estimated by $p_{i}$.

Values nearer to 1 show an extreme rate of diversification and vice versa. For companies with foreign subsidiaries, we divide total exports by total sales (Export/Total Sales)-estimate globalization. 
Rumelt's index (RUM) was incorporated to evaluate degree of diversification or specialization by comparing relatively revenues derived from primary mandate of the firm and total revenues (Rumelt, 1974).

RUM $=\frac{\text { Main Business line Sales }}{\Sigma j \text { Sales in Business } i}$

The data used in estimation was obtained from NSE year book and Central bank of Kenya. Quantity and quality of data was affected to extend that companies treat their business lines confidential to avoid competition in the market. About $25 \%$ of the companies under the study had correlation coefficient of about 0.75 .

This shows that real option value increase as companies diversify their investments in terms of business geographical location and portfolios to reduce financial risks and yield high profits.

\subsection{Operationalization of market value of firm's real option}

Firm's market value is obtained by sum of discounted cash flows of AIA and the real option market value. However due to uncertainty of future events, cash flows must reflect inherent risks associated with business transactions. CAPM beta was employed to measure the entire company's assets (i.e. both already-invested-assets and real options).

The study used current year cash flow as the base and assumed cash flows will be constant to infinite time. Discount rate was approximated in two different ways. First method is the use of CAPM since it factors systemic risks associated with business industry. Second method involves T-bill rate of returns. This enabled us to obtain annual proxy of the already-invested-assets value (AIA1) calculated as a ratio between the expected cash-flows and the systemic risk reflected returns. AIA2 is calculated as PV of returns using T-bill rate. The two; AIA1 and AIA2 give two proxies for the real option (ROVr1 and ROVr2) used to evaluate the proposed hypotheses.

Real options price is a relative of present capital stock prices and already-invested-assets value (AIA1 and AIA2). The study used average industry beta obtained from CBK annual industry index to obtain discount rate proxies. Risk free rate of return is representative of long term bond floated by government. Risk premium of $8 \%$ p.a assumed to be constant for entire period of study which is average of General Index obtained from NSE.

It is expected that AIA $1<\mathrm{AIA} 2$

And hence ROVr1 $>$ ROVr2

This demonstrates that risk free interest rate gives a more robust estimation value of real option compered to use of average industry beta

\subsection{Descriptive Statistics of Real Option Value}

The table 1 below shows portfolio diversification and specialization rate for the firms. Herfindal's index and of Rumelt's ratio examination reveals high degree of specialization with $60 \%$ of sample adopting the approach in their business investments. However, companies are embracing diversification to spread the hazards moderately as seen from year 2013 to 207. Past studies on the diversification strategies (Sua' rez, 1994) show similar trend. Globalization degree estimation is obtained by dividing companies' exports and total sales.

Table 1: Descriptive statistics on corporate diversification and specialization

\begin{tabular}{|l|l|l|l|l|l|}
\hline Measurement & $\mathbf{2 0 1 3}$ & $\mathbf{2 0 1 4}$ & $\mathbf{2 0 1 5}$ & $\mathbf{2 0 1 6}$ & $\mathbf{2 0 1 7}$ \\
\hline HERF & & & & & \\
\hline Mean & .1567 & .1324 & .1434 & .1503 & .1578 \\
\hline SD & .1924 & .1825 & .1903 & .2107 & .2362 \\
\hline Highest & .8421 & .7028 & .6895 & .7836 & .8014 \\
\hline Lowest & 0 & 0 & 0 & 0 & 0 \\
\hline Median & .0638 & .2602 & .1049 & .0694 & .1518 \\
\hline ESP & & & & & .7852 \\
\hline Average & .9204 & .89472 & .9269 & .1837 & 0.8752 \\
\hline SD & .1369 & .1479 & 0.1904 & 1 & 0.1836 \\
\hline Highest & 1 & 1 & 1 & .2836 & 1 \\
\hline Lowest & .3762 & .5207 & .3476 & .9863 & 0.3148 \\
\hline Median & .9264 & .8807 & 1 & 0.9155 \\
\hline
\end{tabular}

The table below shows annual descriptive statistics of real option value estimates. The first two columns represent entire population considered while the last two columns represent the sample. The sample is arrived at after excluding firms with negative values for the already- invested - assets (AIA) or records an extreme values in the ratios ROVr1 and ROVr2. From the results, the mean ofROVr2 is almost half of ROVr1. The values shows an upward trend over the period.

Two ratios are meant to examine more critically the factors that influence real option market value. 
Table 2. Descriptive statistics

\begin{tabular}{|c|c|c|c|c|c|}
\hline Year & Measurement & ROVr1 & ROVr2 & ROVr1 & ROVr2 \\
\hline \multirow[t]{6}{*}{2013} & Average & 1.3987 & 0.7985 & 1.7012 & 1.1031 \\
\hline & Median & 1.0943 & .5932 & 1.3014 & .7340 \\
\hline & Std. Dev. & 1.7201 & 1.1220 & 1.7001 & 1.0397 \\
\hline & Highest & 10.9821 & 6.7035 & 12.093 & 7.2382 \\
\hline & Lowest & -2.9532 & -1.8024 & .1250 & .0756 \\
\hline & Variance coefficient & 1.5994 & 1.2742 & 1.0039 & 1.1027 \\
\hline \multirow[t]{6}{*}{2014} & Average & .9243 & .4983 & 1.4202 & .8522 \\
\hline & Median & .8109 & .5143 & .9727 & .6732 \\
\hline & Std. Dev & 2.0173 & 1.2034 & 1.4093 & .8427 \\
\hline & & 8.3086 & 5.2139 & 7.9759 & 5.3207 \\
\hline & Lowest & -8.7682 & -6.1272 & 0.0783 & .0529 \\
\hline & Variance coefficient & 2.0794 & 2.5295 & 1.0564 & 1.1048 \\
\hline \multirow[t]{6}{*}{2015} & Average & 1.3201 & .6035 & 2.2053 & 1.4020 \\
\hline & Median & 1.2062 & .5784 & 1.7054 & .9241 \\
\hline & Std.Dev & 4.2087 & 2.5012 & 1.8623 & 1.9300 \\
\hline & Highest & 30.4207 & 16.2264 & 8.7562 & 5.8201 \\
\hline & Lowest & -17.3721 & -10.2302 & .3962 & .9489 \\
\hline & Variance coefficient & 4.207 & 3.7837 & .9235 & .8638 \\
\hline \multirow[t]{6}{*}{2016} & Average & 1.8654 & 1.0694 & 2.1078 & 1.2310 \\
\hline & Median & 1.6202 & .8473 & 1.7036 & .8947 \\
\hline & Std.Dev & 6.9869 & 4.7461 & 1.9673 & 1.1068 \\
\hline & Highest & 67.3292 & 40.2401 & 12.9683 & 7.1047 \\
\hline & Lowest & -16.7863 & -8.89 & .3472 & .1785 \\
\hline & Variance coefficient & 3.9696 & 4.8403 & .9726 & .9207 \\
\hline \multirow[t]{6}{*}{2017} & Average & 1.8604 & 1.2473 & 2.3421 & 1.7847 \\
\hline & Median & 1.3762 & .8472 & 1.6394 & 0.8674 \\
\hline & Std.Dev & 2.2744 & 1.4087 & 2.0985 & 1.3405 \\
\hline & Highest & 14.8953 & 8.7482 & 13.0537 & 8.5932 \\
\hline & Lowest & -3.7428 & -2.6303 & .1536 & 0.0864 \\
\hline & Variance coefficient & 1.4791 & 1.3942 & 1.0753 & 1.1068 \\
\hline
\end{tabular}

\subsection{Regression Analysis}

HMR model was applied to examine the association between internal diversification and real option value. This model tested hypothesis $\mathrm{H} 1$ as follows:

$$
\mathrm{ROV}_{\mathrm{it}}=\beta_{0}+\beta_{1} \mathrm{HERF}_{\mathrm{it}}+\beta_{2} \mathrm{ESP}_{\mathrm{it}}+\beta_{3} \mathrm{RUM}_{\mathrm{it}}+\varepsilon_{\mathrm{it}}
$$

Where: $-\mathrm{ROV}_{\mathrm{it}}$ - is the Real Option Value ratio of the total market value; $\beta_{0}$ is eqn. constant $\beta_{1} \ldots . . \beta_{3}-$ are the regression coefficients, $\mathrm{HERF}_{\mathrm{it}}-\mathrm{Herfindahl}_{\text {Index }}$ - Measures the level of internal diversification; ESP $\mathrm{Et}_{\text {it }}$ measure globalization; RUM ${ }_{\text {it }}$ - degree of specialization or focus; $\varepsilon_{\mathrm{i}}$ - is a random error term that accounts for the unexplained variations.

\subsection{Hypothesis Testing}

Study objective was to establish the impact of real option diversification on capital prices of a firm. Study predicted that the impact of corporate diversification on real option value of company listed at the NSE not significant. Corporate diversification measures include measure or internal diversification (Herfindahl), degree of specialization (RUM Index) and globalization -ESP (Export/Total Sales). Real Option Value ratio (ROVr) was calculated for each firm. HMR analysis was employed to examine if internal diversification, degree of specialization and globalization significantly predicted real option values of firms listed at the NSE. This formed basis of the first null hypothesis.

Hypothesis $H_{O 1}$ : The impact of corporate diversification on real option values of firms listed at the NSE not significant

Three steps were used in carrying out the HMR. The first step involves internal diversification against real option value. Second step involves internal diversification and degree of specialization against real option. The third step involved internal diversification, degree of specialization and globalization against real option value. The results are shown below; 
Table 3: Corporate diversification and Real Option value

\begin{tabular}{|l|l|l|l|}
\hline & Model 1 $^{\mathbf{a}}$ & Model 2 $^{\mathbf{b}}$ & Model 3 $^{\mathbf{c}}$ \\
\hline Constant & $0.087(.045)$ & $0.204(.015)$ & $0.138(.072)$ \\
\hline Internal diversification (Herfindahl) & $0.219(.000)$ & $0.229(.000)$ & $0.230(.000)$ \\
\hline degree of specialization (RUM Index) & & $-0.153(.025)$ & $-.158(.053)$ \\
\hline globalization (ESP) & & & $0.205(.0335)$ \\
\hline Adjusted R & & $\mathbf{0 . 6 5 1}$ & $\mathbf{0 . 7 0 4}$ \\
\hline F & $\mathbf{0 . 6 2 3}$ & $\mathbf{8 2 . 2 1 4 ( . 0 0 0 )}$ & $\mathbf{4 8 . 9 7 3 ( . 0 0 0 )}$ \\
\hline & $\mathbf{1 5 2 . 3 2 2 ( . 0 0 0 )}$ & & \\
\hline
\end{tabular}

Source: Author, 2018

p-Values in parenthesis;

a. Predictor; Internal diversification

b. Predictor; Internal diversification, degree of specialization

c. Predictor; Internal diversification, degree of specialization and globalization

Internal diversification Model. 1 had $\mathrm{F}=152.322, \mathrm{p}<.05$, Model. 2 with internal diversification and degree of specialization as a sub variable of corporate diversification had $\mathrm{F}=82.214, \mathrm{p}<.05$ while model 3 of globalization sub variable and other two variables had $(\mathrm{F}=48.973, \mathrm{p}<.05)$.

Adjusted coefficient of $\bar{R}^{2}$ was highest Model 3 at 0.704 and lowest in Model 1 at 0.623 . The three models show significant relationship between variables, they were subjected to slope test to determine strength of relationship. Model three shows that internal diversification $(\beta=0.230, p<.05)$, degree of specialization $(\beta=$ $0.158, \mathrm{p}<.05)$ and globalization $(\beta=-0.205, \mathrm{p}<.05)$ were good independent variables of real option value. Model two shows that both internal diversification $(\beta=-.229, \mathrm{p}<.05)$ and degree of specialization $(\beta=-0.153, \mathrm{p}<.05)$ were good predictors of real option value. Although model one with only internal diversification $(\beta=0.219$, $\mathrm{p}<.05)$ as independent variable was also good in predicting real option value, models two and three were better since they have two and three independent variables respectively.

From the results, real option market value is positively and significantly associated with internal diversification $(p<0.05)$ but negatively related to degree of specialization. Also there is a positive significant relationship between real option value and globalization. Therefore, there is a significant relationship between corporate diversification and real option component of market value of stock for firms listed at the NSE in Kenya resulting in the rejection of hypothesis one $\left(\mathrm{H}_{1}\right)$.

\subsection{Findings and Discussions}

The results refer based on 260 annual observations for the period 2013 through 2017. The sample was obtained by eliminating firms with negative net cash-flow or extreme values of ROVr1 or ROVr2. The two ratios give regression coefficient values as predicted, although internal diversification significance is at $1 \%$. The result shows that firms are adopting real option in their quest to grow by diversifying their business lines and locations. These findings were in agreement with past studies. Alonso et al. (2006) argues that efficient valuation of a firm is a composition of already acquired assets and future investment which company has resources and capacity to execute. These were also supported by Kogut and Kulatilaka (2001) in his bid to provide theoretical foundations to use heurestics for deriving capabilities found that, integration of skilled workforce and technology gives a company higher real option market value.

Real option diversification is a key component in determining market value of a firm. Companies achieve diversification by having different business lines and competitive/strategic geographical location of business. The study used data collected from the sixty four listed companies at NSE from 2013-2017. After analysis the results reveal a positive significant relationship between corporate diversification and market value of real option. Real option contributes to greater extend the valuation of firm stock price in capital markets. Investors pay more attention to company's ability to effectively hold their real option than its present resources to execute available portfolio opportunities.

Kester (1984) argues that investments held now for future execution accounts significant percentage of firm's capital price. Raffaele and Maurizo (2010) set out to analyse the valuation of R\&D by stock market within the perspective of real option Theory. He found a direct impact of the R\&D capital on firm's stock price and variability of this effect over time and across industries. Rogier (2013) studied market value of technology application by firms within real options perspective. His objective was to determine when and how Real-Option theory could be applied to improve the overall company valuation. The finding was that real options are more than a rights on a company traded assets and that Real Option theory represent an important tool to value flexibility. 


\subsection{Conclusion}

It is evident that firms globally are embracing portfolio and location diversification to enhance growth and flexibility. Based on HREF values, diversification has direct and significant impact on firm's value in capital markets. However specializing in one area of business ties the firm from exploiting other equally profitable ventures hence affecting firms' value growth negatively. Investors are more concerned with how the management positions itself to acquire and exploit market fortunes other than value of already acquired assets accumulation. Real option strategy in investing reduces completion and enhance to a greater extend capital prices of the firm. This was also supported by the conclusion of Salma and Hussain (2018) that debt ratio and firm risk significantly influence corporate value when the portfolios are well diversified. The study concluded that corporate diversification in portfolios and location has a direct significant impact on market value of firm in financial market.

\subsection{Contribution of the study}

The study provides fundamental foundation of what management has to do to economically and strategically allocate resources. Flexibility in investments going into future has a value of substantial proportion in capital markets. Management will gain insights to improve strategic decision making by bringing financial discipline in strategic planning tools, and also by incorporating strategic realities into traditional capital budgeting models that do not explicitly account for the value of flexibility and managerial discretion. It will therefore form a base for future academic research. It provides policy discussions to deliver a level playing field for investors, NSE and other authorities through the knowledge of relationships between the key variables and option value of stocks. Policy harmonization agencies would benefit from understanding the market value of stocks and its proper analysis and valuation. The study recommends for robust analytical research on alternative measures of investors' expectations on the management ability to strategically exploit different profitable ventures in the markets.

\section{References}

Adam, T. \& Goyal, V. K. (2002).The investment opportunity set and its proxy variables: theory and evidence, SSRN Electronic Paper Collection, February.

Amram, M.,\& Kulatilaka, N. (1999). Disciplined decisions: aligning strategy with the financial markets. Harvard business review (February), 95-104.

Black, F \& Scholes, M. (1973). The pricing option and corporate liabilities. J Finance 32.

Bloom N., Bond S. \& John Van, J. R (2001). Uncertainty and Investment Dynamics, Stanford University, Centre for Economic Performance and Institute of Fiscal Studies, University of Oxford.

Bowman, E. H. \& Hurry, D. (1993). Strategy through the option lens: an integrated view of resource investments and the incremental-choice process, Academy of Management Review, 18, 760-82.

Danbolt, J., Hirst, I. \& Jones, E. (2002). Measuring growth opportunities, Applied Financial Economics, 2, 203212

Dominic, O. O., \&Memba, F. (2015). Effect of corporate governance practices on financial performance of public limited companies in Kenya. International Journal of Management and Commerce Innovations, 3(1), $122-132$.

Dixit, A. K. \&Pindcyck, R. S. (1994). Investment Under Uncertainty, Princeton University Press, Princeton NJ.

Fama, E.F. (1970). Efficient Capital Markets: A review of theory and Empirical work, Journal of Finance, $23,383-417$

F. Peter, F. B, (2002). Finding the total value in high risk firms, Published by John Wiley \& Sons, Inc., New York. www. WileyFinance.com.

Gujarati, D. (2003). Basic Econometrics. 4thed. New York: McGraw Hill, 638-640.

Hirschman, A. O., (1964). The paternity of an index, American Economic Review,54, 761-2.

Huber, P. J. (1973) Robust Regression: Asymptotics, Conjectures and Monte Carlo. The Annals of Statistics, 1, 799-821.

Kempf, A., \&Osthoff, (2007).The effects of social responsibility investment on portfolio performance.European Financial Management Journal, 13, 908-922.

Kester W.C (1984). Today's option for tomorrow's growth. Harvard Business Review 53-60

Kline, R.B. (2010). Convergence of structural equation modeling and multilevel modeling. London: Oxford university press

Kogut, B. \& Kulatilaka, N. (2001). Capabilities as Real Option, Organization Science 12(6), $744-$ 758.http://dx.doi.org/10.1287/ orsc.12.6.744.10082

Lyandres E, Marchica MT, Michaely R, Mura R (2015) Owners' portfolio diversification and firm investment: Evidence from private and public firms.SSRN Working Paper.

Myers, S. C. (1977). Determinants of corporate borrowing, Journal of Financial Economics, 5, 145-75. 
Pablo de Andres-Alonso, Valentın Azofra-Palenzuela and Gabriel de la Fuente-Herrero (2005). Real options as a component of the market value of stocks: evidence from the Spanish Stock Market, Department of Financial Economics and Accounting, University of Valladolid, Avda. Valle Esgueva, 6, 47011-Valladolid, Spain.

Pablo de Andres-Alonso, Valentın Azofra-Palenzuela and Gabriel de la Fuente- errero (2006). The Real Options Component of Firm Market Value: The Case of the Technological Corporation, Journal of Business Finance \& Accounting, 33(1) \& (2), 203-219.

Paddock,J.L.,Siegel,D.R.\&Smith,J.L.(1988). Option valuation of claims on real assets: the case of o shore petroleum leases.Quarterly Journal of Economics, 103, 479-508.

Pandey, I. M. (2004). Financial Management. Ninth Revised Edition, Vikas, India

Pindyck, R.S. (1991). Irreversibility, uncertainty, and investment. J. Economics. Literature. 29 (3) 1110-1148.

Quigg, L. (1993) Empirical testing of real option-pricing models, Journal of Finance,48, 621-640.

RaffaeleOrieni and Maurizio Sobrero, (2010). Market valuation of Firm's Technological Knowledge: A Real Options Perspective. 21st Annual International Conference of Strategic Management Society, $21-24$ October, San Francisco, CA.

Rita D. G. M., \& Atul N., (2004). Real Option Reasoning and a New look at the R\&D Investment Strategies of Pharmaceutical Firms.Strategic Management Journal, 5(3), 54 - 75.

Rumelt, R.P.(1974).Strategy, Structure and Economic Performance, Harvard University Press, Cambridge, MA.

Rogier V. A. (2013). A Real-Option approach to company valuation. University of Twente, Financial Engineering and management.

Salma, U \& Hussain, A. (2018). A comparative study of corporate diversification and firm performance across South Asia Countries. Journal of Accounting and Marketing,7(1), 32 - 53.

Sanchez R. (1993). Strategic flexibility, firm organization, and managerial work in dynamic markets: a strategic options perspective. In Advances in Strategic Management, Shrivastrava P, Huff A, Dutton J (eds). JAI Press: Greenwich, CT; 251-291.

Sekaran U. (1992). Research Method for Business: A skill Building Approach (2nded.). John Wiley Sons, Inc

Sharp, D. J. (1991).Uncovering the hidden value in high-risk investments. Sloan Management Review, 32, 69-74.

Smit, H. T. J. (2000).Option characteristics of growth stocks, in 4th Annual International Conference on Real Options: Theory Meets Practice. Cambridge University.

Statman, M. (2000).Socially responsible mutual funds.Financial.Analysts Journal, 13, 30-39.

Sua'rez, I. (1994) Estrategia de diversificacio' n y resultados de la empresaespan ola, Revista de Economi'aAplicada, 2, 103-28.

Trigeorgis, L. G. (1996). Real Options. Managerial Flexibility and Strategy in Resource Allocation. MIT Press, Cambridge, MA. 